\title{
Contextual Aspects of Style and Translation: With Particular Reference to English-Arabic Translation
}

\author{
Fadil Elmenfi ${ }^{1}$ \\ ${ }^{1}$ Department of English, Omar Al-Mukhtar University, Derna, Libya \\ Correspondence: Fadil Elmenfi, P. O. Box 82, Department of English, Omar Al-Mukhtar University, Derna, \\ Libya. Tel: 218-91-836-0743. E-mail: fadil.elmenfi@gmail.com
}

Received: November 18, 2013 Accepted: January 19, $2014 \quad$ Online Published: February 21, 2014

doi:10.5539/ells.v4n1p33 URL: http://dx.doi.org/10.5539/ells.v4n1p33

\begin{abstract}
Some activities are easier to practice than to talk about, translation is one of them. This is simply because translation as a practice existed long before translation as a theoretical discipline. Most translators with no doubt wish to see their role in such a positive way: "opening a window" for TT readers, in order to illuminate for them an unfamiliar culture. In today's translation circles, the translations accepted by mainstream translation norms more often than not share such features as fluency, smoothness and transparency. The target text is free of the slightest trace of translation and reads as if it had been written by the original author in the target language. The differences, including the strangeness, and otherness, are replaced by something familiar to the target reader. This paper, is basically devoted to shedding light on the impact of Abu Deeb's style, in translating Orientalism, and how Abu Deeb's style effect his translation.
\end{abstract}

Keywords: style, translation, Edward Said, Kamal Abu Deeb, Orientalism

\section{Introduction}

It is true that the writer has his/her particular stylistic/linguistic choices whether consciously or not; it is also true that the author is the producer of his/her texts and has preferences and certain intentions in mind, so is it not true that he/she is the owner of his/her text which he/she directs to the reader? Moreover, some writers as they write a certain text may be intending one thing, but they may change their mind later on.

Stylistic translation stresses the overlap between message and style. To render the former as correctly as possible into the TL we need to choose the proper style to accommodate it. This style should be faithful to that of the SL text and at the same time appropriate to the TL text whenever possible. Respectively, style or how it is expressed is inseparable from and part of the message or what is said.

On the one hand, Edward Said, who was born on 1st November 1935 and died on 25th September 2003, was a Palestinian-American author, acclaimed literary critic and professor of English and Comparative Literature at Columbia University for more than four decades. Said was a prolific writer as the author of more than 20 books during his lifetime. Said had his own style which hardly anyone shared with him, as he always relied on literary texts as well as cultural texts, based on academic methods of research in literary criticism. His style was received with difficulty by the reader, even in English-speaking countries because of his many digressions, and being aware of the characteristics of academic writing in the humanities where it is difficult to generalize. Tom Paulin in his article "Writing to the moment" which was published in The Guardian (25 September 2004) says that "The cadences of Said's prose resist the consistency of plain style", as when he argues that the intellectual must choose 'the method, the style, the texture' best suited for the purpose of saying the truth to power. The texture of his prose challenges that blurred, evasive, timid judiciousness which lies at the heart of much academic writing. His prose is pitched against what he calls 'the academic flaccidity' of English Studies, the determination of its practitioners to show themselves 'to be silent, perhaps incompetent' about the social and historical world."

Furthermore, Moustafa Bayoumi and Andrew Rubin, the editors of the book Edward Said Reader, refer to Noam Chomsky (2002, p. 6) as describing Said's intellectual contribution as follows: "His scholarly work has been devoted to unravelling mythologies about ourselves and our interpretation of others, reshaping our perceptions of what the rest of the world is and what we are."

Finally, it is widely known that authors have their own personal intentions and stylistic choices. However, these 
intentions and choices are constructed in the author's mental, social, cultural and ideological environment, which might not apply to readers/translators who may have a completely different environment.

\section{Style and Translation}

There are a number of definitions of style and no particular definition is agreed upon to be the ultimate definition; the Encarta English Dictionary, for example, lists ten definitions of style. The third definition says that style is a way of writing or performing: the way in which something is written or performed as distinct from the content of the writing or performance. This is where we commence our discussion. So style can mean different kinds of things. Looking at the definition, we can see that style is used as a term distinct from content in writing and it stresses form or format.

Furthermore, style is an essential feature in every piece of writing, the outcome of the writer's character and his emotions at the time, and no paragraph can be constructed without revealing, to some extent, the personality of its author. A universal thought is that each writer has a literary style and that his writing reflects his style. It goes without saying that different literary works have discernibly different styles.

The discussion of faithfulness to content has always been emphasized and dealt with seriously, but faithfulness to style seems to contain more difficulties. Style in literature is the novelist's choice of words and phrases, and the way he constructs sentences and paragraphs by arranging those words and phrases. Style allows the author to shape how the reader experiences the work. For instance, one writer may use clear, simple words, and direct sentences, while another may use more complex vocabulary and elaborate sentence structures. Even if the themes of both works are similar, the differences in the authors' styles make the experiences of reading the two works different.

\subsection{Translator's Style}

Malmkjaer (2004) uses the term "translational stylistics" to describe those studies concerned with the recreation of the translator's choices made in the TT. Translational stylistics is a special type of stylistics that views the TT in its relation to the ST. However, stylistic differences between two translations of the same text are evidence of different interpretations on the part of the two translators of the cognitive state combined in the text. Until now, the focus on the translator's style and stylistic choices has been on the TT. Before that, and as a preliminary to this stage, the translator makes his/her choices, which are certainly not identical to those made by the writer of the ST. The new proposition of "co-authoring" in translation studies may be borrowed from recent literary studies which consider the reader as a co-author of the text, and by analogy, the same applies to the translator. Both the translator's and the author's voices co-exist in the rendered text. Among the translation theorists who have attended to the stylistics of the translated text is Venuti (2000) who has pointed to an interaction between the visible presence of the translator in the target text and the presence of the author in the source text. The models of domestication and foreignization proposed by Venuti will be discussed in greater details in the coming pages.

The factors that influence the translator's stylistic choices and state of mind are another point of interest. The translator has his/her own style, choices, likes, dislikes, social, cultural, religious, mental, ideological, political and attitudinal background, personal experience and knowledge and view of the world like any regular reader. Thus, it is self-evident that these factors affect the translator's style of translation and they will be reflected in his rendered text.

Recently, in relation to reader-response theory, relevance theory, text world theory and the translator's style and approach to the processing of the ST in terms of cognitive stylistics, some writers (e.g., Mackenzie, Sperber and Wilson and others) have come to view the translator as a writer. According to them the translator is the writer of the translation who is responsible for the style of the translated text which readers of the translation respond to and from which he/she creates meaning. Thus, the translator has the role of a writer who motivates discovery in the reader (see Boase-Beier, 2006, p. 51). The text, according to Sperber and Wilson (1995) and other proponents of text world theories, apart from imposing some structure on the reader's experience, has no restrictions on the meanings it is possible for the reader to construct. The onus in these theories is on the reader (or translator) to construct meaning by guidance from the text (see also Iser, 1979). Besides, the author can be responsible only for certain guidance offered to readers/translators.

The translator is the writer and creator of the translation in two senses: first, without a translator, a TT would not come into existence; secondly, the translator is the former of the translated text out of the ST. He/she is not merely reproducing, reconstructing, or recreating the author's meaning in the original into the target text. $\mathrm{He} / \mathrm{she}$ reads and understands the original on its author's terms and conditions, to construct it on his/her terms and 
conditions of background knowledge, culture, ideology, experience, conventions, etc.

\subsection{Style and Fidelity}

Generally, it is impossible to find an expression in one language that is entirely equivalent to one in another as each language has its way of idiomatic collocations. Faithfulness is generally considered to be one of the most important elements in achieving a high level of correctness and accuracy. However, as Venuti (2000, p. 21) notes, fidelity in the translation of individual words can almost never fully reproduce their original meaning.

The translator has several responsibilities towards the source text author. According to Chesterman (1997, p. 169) the translator has to seek a balance of loyalty to both sides, that is to say, he has to remain in a central position in which he achieves with both the author's message and the competent reader's comprehension. Venuti (2000, p. 60) views this matter as an "either/or" situation, in terms of either the translator leaving the author in peace as much as possible and moving the reader towards him, or doing the opposite in which he leaves the reader in peace as much as possible and moves the author towards him. He comments on Schleiermacher's approach to the different methods of translating, by stating that Schleiermacher argues that translation can move in either direction, i.e., whether the author is brought to the reader's language or the reader is carried to the author's language. In the first case, we do not translate words in the proper sense; we, in fact, apply a kind of paraphrase to the original text. It is only when we force the reader from his linguistic habits and oblige him to move within those of the author that there is actually translation. This view, to a large extent, is reflected in Venuti's strategy, foreignizing, as opposed to domesticating strategy.

The translator has to consider whether a text is literary or non-literary, a distinction that has its results in the analysis and interpretation of the text, for the major differences in style between the two types. The different styles of the text language (formal, colloquial, etc.) have to be seriously considered by the translator for their important reflections on the interpretation, and hence translation, of the text.

\section{The Translation of Orientalism}

Kamal Abu Deeb, the Syrian intellectual, was the first to translate Edward Said's book, Orientalism, into Arabic. His translation was criticized intensively, because of more than one aspect. The most controversial reason is the new Arabic vocabularies that he invented and which did not have any history or Arabic background. Abu Deeb, in fact, tried to do something unique that would differentiate him from other writers and translators.

In 1981, the first translation of Orientalism appeared, undertaken by Kamal Abu Deeb; it was very difficult and complex. In this respect, Sabry Hafez $(2004$, p. 82) states that "Aside from obfuscating his brilliant argument, the translation had an enormous negative impact on his legacy and the perception or misperception of his work among Arab intellectuals. Its thick verbosity, pretentious terminology, and confused vocabulary associated him with the type of sterile and problematic language that was the hallmark of the coterie of Adonis, a clique that clung to Said for some time and complicated the way he was perceived in Arab intellectual circles for years". He goes on to say that "though the message of Said's Orientalism was distorted in Arab intellectual circles and indeed among the wider public through the traditionalists' widely disseminated misrepresentation of his main thesis as a kind of identity politics, the book did spark wide debate on the issues it addressed". By the same token, Edward Said himself, in the last chapter of Orientalism which he added to the 1995 edition and which was published after the Arabic translation of Abu Deeb appeared, described Abu Deeb's translation as having differences and made many comments on it.

The translation of Abu Deeb was criticized by a number of Arab writers who thought that his way of translating the book made the book rather difficult to understand. For example, Muhammad Al-Ahamari (2003), in his eulogy of Said in the article "Edward Said: If he was a Muslim, We would Seek Allah's Mercy for him" which was published in Al-Așr Magazine مجلة العصر on September 27th 2003, notes that Orientalism is not translated well and that Abu Deeb's translation is ambiguous and destroys the work of Said. In this respect, Al-Ahamari (2003) states that "I wish that the Arab reader had Orientalism in a new translation as the translator [Abu Deeb] foreignised and damaged his [Said's] writing. If you compare these translations [Abu Deeb's] and other translations [of Said's books] such as the translation of Representations of the Intellectual or the book [featuring] the long interview with him [i.e., Said] conducted by David Barsamian, you will see the difference between the two approaches."

Abu Deeb made a great effort to almost completely avoid using western expressions which already exist in Arabic. According to Edward Said: "I regret to say that the Arabic reception of Orientalism, despite Kamal Abu Deeb's remarkable translation, still managed to ignore that aspect of my book which diminished the nationalist fervour that some inferred from my critique of Orientalism, which I associated with those driven to domination 
and control, also to be found in imperialism. The main achievement of Abu Deeb's painstaking translation was an almost total avoidance of Arabized Western expressions; technical words like discourse, simulacrum, paradigm, or code were rendered from within the classical rhetoric of the Arab tradition. His idea was to place my work inside one fully formed tradition, as if it were addressing another from the perspective of cultural adequacy and equality." (Said, 1978, 2003, p. 339)

Kamal Abu Deeb decided to restrict himself voluntarily to what he called representation of the translated text, which means representing the entire structure of the text, not an idea only. He started by alluding to the difficulty of Edward Said's book in both reading and translating. The sources of difficulty in the translation of Orientalism are not a single dimension, but multiple. The difficulty lies in Orientalism as much as in the development of the Arabic language. Edward Said is able to deal with language in all dimensions. In respect of such a thought, one's response is not determined in the context of easy and difficult, but in a different context and at a different level: the level of ability to use the most difficult level in analysis, the most ambiguous concepts in the discussion of what seems ordinary (see Abu Deeb, 1981, 1995, p. 9).

In the coming discussion we will see how Abu Deeb's translation followed a new method of translation as a pretext to enrich Arabic literature and culture. The severe criticism that this translation generated among Arab intellectuals, together with the opaqueness of its language, may thus have motivated the retranslation of the same text after a quarter a century.

Sixteen years after he produced his translation of Orientalism (1981), Abu Deeb published an Arabic translation of Said's Culture and Imperialism and imbued it with the same narratives of language and translation.

\subsection{Situating Abu Deeb in Context}

The translation of Orientalism by Abu Deeb in $(1981,1995)$ included as an introduction an analysis of his translation process by which he treated the transformations which exist in the translated text. Abu Deeb (1981, 1995: p. 10) believed that if this analysis was able to be understood easily, then the process of translation would be much better. In a brief statement in the introductory part of his translation of Orientalism Abu Deeb (ibid, p. 10) has clearly shown that the translation process reproduces the rendered text in such a way that it assumes the necessity of recognizing its comprehensive structural features, in addition to reproducing the text in a language which is able to embody these features and the structural features to the maximum. By this he meant not only rendering an intellectual message from one language to another, but taking into account the structure and form (the morphological elements) of the sentence. Abu Deeb (1981, 1995, p. 14) carries on to say that the objectives for his translation are "to embody, as much as possible, the structure of the thoughts that create an effective discourse and to contribute to extending the structure of the target language to accommodate this discourse". According to the previous statement we may judge that Abu Deeb is attempting to apply the structuralist approach in translating texts.

Al-Herthani (2009, p. 117) notes that Abu Deeb's "commitment to revive the Arabic language may be a part of his extended project aiming to renew the studies of Arabic literary culture through structuralism". Abu Deeb sees this not only as a way of reviving language, but as a fundamental [radical] revolutionization of thought, its relation with the world and its position within it (see Abu Deeb, 1979, p. 7).

Structuralism does not change language or society as such, Abu Deeb argues, but it changes the way in which both language and social relations are perceived. Abu Deeb's espousal of structuralism rests on his belief that it is able to change the thought that conceptualises language, society and poetry (see Abu Deeb, ibid, p. 7).

Abu Deeb's project, and in particular his support for structuralism, produced two different reactions among other scholars of Arabic literary criticism: the first group considered his work as an innovative conceptual narrative that provided a new method of research, a method that attempted to enrich Arab culture; while the other group believed Abu Deeb was a dissident who aimed to damage the Arab culture and encourage whatever was related to the West. Dr. Abdulaziz Al-Maqaleh (from Yemen) (2000, p. 15) notes that Kamal Abu Deeb applied the principles of structuralism and that he was able to connect contemporary Arab literary criticism rooted in history. Dr. Al-Maqaleh presented a critical paper on the celebrated intellectual entitled "Laud of Friendship" at the Sana'a Forum for Young Poets when they held their Second Forum for Young Arab Poets on April 22-26 2009 at the cultural centre in Sana'a, in which he pointed out that Abu Deeb should be recognized precisely for the important change he made to the structure of modern Arab criticism. He added that Abu Deeb was one of the few Arabs who had experienced the West and recognized the dimension of its imperial project as an attempt to control the world culturally and politically. Al-Maqaleh noted that Kamal Abu Deeb and Edward Said were similar and worked together toward the same target which was to correct the ruined image of Arabs in the West. Both realized the value of modernism as an inevitable necessity in life, literature and the arts, and defending the 
numerous conventional styles in literary creation and criticism. He said that both men offered the West more than they gained from it.

The Egyptian, Salah Fadl, in the same context, supported Al-Maqaleh's point of view on Abu Deeb's approach. He also expressed his admiration and congratulated Kamal Abu Deeb for his intellectual contributions to Structuralism theory in Arabic literature. In his article in Al-Ahram Magazine (2006) entitled "On Admiring Kamal Abu Deeb and his criticism", Salah Fadl declares that Abu Deeb worked very hard to structuralise the principles of Arabic poetics, and revolutionise critical discourse as a whole through his writings, though it could be said that an initial contribution had been inherent in the poetry of Arabic literature since Abu Nuwas, Abu Tammam (Habib ibn Aws Al-Ta'i), even Adonis, whose contribution could be considered important in enriching Arabic poetry.

Jabir Asfur agrees with Fadl and Al-Maqaleh that Abu Deeb's approach was a great achievement in improving Arabic literature. Asfur (2007) states that he is fascinated by Abu Deeb's endeavour to apply structuralist criticism to Arabic poetry, describing it as a pioneering attempt that constitutes a truly innovative launching pad for a new concept of studying Arabic poetry. Asfur (2007) goes on to say that he read Abu Deeb's article "Towards a Structural Analysis of Pre-Islamic Poetry" three times, each time admiring his approach more and more.

On the other hand, there are some people who do not agree with Abu Deeb's approach, defending their disagreement with the notion that Abu Deeb was fascinated by the western style and merely wished to westernize Arab brains. Among these critics is Abdul Aziz Hammuda, who was the first to refute Abu Deeb's approach and the theory of modernism in general.

In his interview with El-Madina magazine, Hammuda (1998, p. 18), states that "Abu Deeb's analysis of 'Mu'allaqat Imru'ul Qays' was a very long analysis which attempted to force the poem to give another meaning which does not exist in the poem, and this process of analysis led to more ambiguity."

Moreover, Hammuda described Abu Deeb as one of those who tried to stereotype the Arab intellectual, and Westernization by attempting to impose an analytical approach on Arabic literature.

Al Herthani mentions two scholars who are in an agreement with Hammuda; they are Sad Al-bazi and Mijan Al-ruwili (2002). Al-Herthani (2009, p. 117) described and summarised several reservations regarding Abu Deeb's conceptual approach expressed by the two, saying that Kamal Abu Deeb's writings are [described as] barely intelligible; indeed, he specifically sets out to write in an obscure style. Then they commented on Abu Deeb's repeated claim of methodological innovativeness as having no supporting evidence, and finally, they claim that Abu Deeb's writing is confused and gives evidence of misrepresenting the sources he draws upon.

Abu Deeb does not locate his strategies of translation within the frame of structuralism. Despite that, Al-Herthani (ibid, p. 119), notes that the effect of the structuralist narrative is obvious in the work of Abu Deeb as a translator, in the main texts of the translations of Orientalism and Culture and Imperialism.

According to Abdul Aziz Hammuda (1998, p. 155) simplification, whether it affects the meaning or not, is a horrible crime against structuralism according to structuralists. Regarding this point, Abu Deeb's translation of Orientalism has been characterized by a number of Arabic critics and readers as obscurity of expression (not adapting the style of simplification), and this ambiguity leads us to imagine that Edward Said's book is a book which contains a lot of information that is difficult to obtain. In this respect, Asa'ad Abukhalil insists that Abu Deeb's translation is not successful precisely because he invented his own terminology. Asa'ad Abukhalil (2003, p. 12) states that "Abu Deeb's translation was not successful at all; he translated according to his whim, coining phrases and terms of his own even where these differed in meaning from the source text."

The role played by Abu Deeb as a reader/translator of Said's text is crucial. Al-Herthani (2009, p. 119) states that the reader's reading/interpreting of the text is given primary position since the text's author is regarded, metaphorically, as "dead" once his/her text is completed. The reader is allowed to look at the text from any angle he wants; the text is free of the original author's intention, and the original text itself has no existence. The reader's reading becomes the only present activity in this new vacuum which accompanies the author's death and the absence of the text; thus the author in the structuralist perspective is dead and there is no place whatsoever for his intention (see Hammuda, 1998).

\subsection{The Syntax Logic in Abu Deeb's Translation}

Matching word with word, structure with structure and sentence with sentence is Abu Deeb's approach to translation. He is able to deal with the original text without explaining or simplifying it. According to Abu Deeb (1981, 1995, p. 12) this needs courage, innovation and adventure to deal with the language as a continuous 
process of creating idioms and coining new terms and not to regard the language as a sacred issue.

When Abu Deeb began his translation of Orientalism, he gave the book a subtitle which could suggest some other subject other than the actual one which is contained within the book. The main Arabic title, الاستشر اق, is the standard equivalent of the English word Orientalism. The choice of the subtitle in Arabic was controversial; while the original subtitle is Western Conceptions of the Orient; Abu Deeb in his rendered version decided to change it to المعرفة. السلطة. الإنشاء (Knowledge. Power. Discourse). This subtitle makes the reader concentrate on the broader issue of the relationship between power, knowledge and discourse that is arranged by Abu Deeb as a frame to understand the particular relationship of the West and the Orient (see Al-Herthani, 2009). However, the full stop after each word could be an indication that each one is a topic on its own.

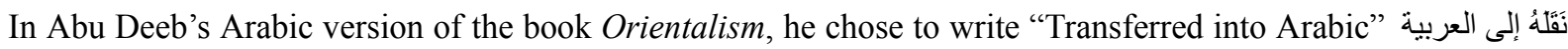
rather than "Translated" تَرْجَمَة, while he wrote on the Arabic version of Culture and Imperialism "Translated"

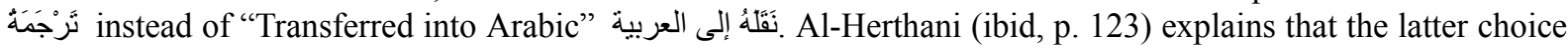
of Abu Deeb "نَقَلَهُ إلى العربية" hints at his own conceptual narrative of translation and what it includes and, to be precise, he explains Abu Deeb's usage of the word "naqalahu" (transferred) rather than "tarjamahu" (translated) by saying that the latter is not an Arabic word and as a result it has been badly used by translators. More essentially, Al-Herthani asked Abu Deeb and his answer was that he tried to transpose the text with its complex features, visible and invisible, from the source language to the target language. He did not just translate meaning.

In this respect, Abu Deeb (1981, 1995, p. 10) notes that "this imploding (Note 1) will not take place unless we indulge in a pioneering adventure, unless we dare to transfer not only ideas from the world but also boldly review the language, its deep and surface structures, its phonetic, morphological and syntactic components; this daring [adventure] ultimately aims at an essential achievement: expanding the language."

$$
\begin{aligned}
& \text { ولن يتم هذا التفجير، في تصوري، إلا بالمغامرة الرائدة، بالجر أة لا على نقل الفكر من العالم وحسب بل على اللغة أيضأ، على بناها العميقة }
\end{aligned}
$$

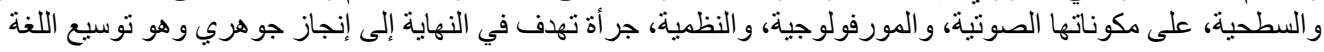

$$
\begin{aligned}
& \text { (كمال أبوديب, 1981, 1995, p. 10) }
\end{aligned}
$$

Keeping this concept in mind we may conclude that Abu Deeb's approach is the total assimilation of the ST, at the same time retaining the structural features of the ST, because the text's message alone is not satisfactory. In the scales of translation procedures by Vinay and Darbelnet (1995) this definition of restrictions on translation was represented as being more inclined towards literal translation than free translation. Abu Deeb rejects the traditional techniques of translation which replace the structures of the ST with those of the TT and make the TT suit the source text's language structure. As a result Abu Deeb (1981, 1995, p. 14) announces the aims of his translation which are to represent the structure of the thoughts that help to make an effective discourse and to achieve the extension of the target language structure and thus give what is needed for this discourse.

Contextually, Abu Deeb (1981, 1995, p. 14) notes that he could write Orientalism in a way that is different from that of Said, but the resultant text will reflect my own style and my personal interact with the Arabic language. On the same subject, Al-Herthani (2009, p. 146) declares that Abu Deeb tries to show that he deserves the same importance and treatment that Said had already received, reminding us that he (Abu Deeb) is able to produce his personal discourse as well as generating his personal debates.

\subsection{Coining New Words and Style Effects}

Abu Deeb tried to treat the incapability of the Arabic language through developing some new terms. For example, the word استبناء is a rendered Arabic word for the English one "restructuring", containing two Arabic morphemes: the prefix است is in place of the English prefix "re" and the root stands for "constructing". The most common Arabic equivalent for the prefix "re" is إعادة (a noun literally meaning "doing the action again", "repeating").

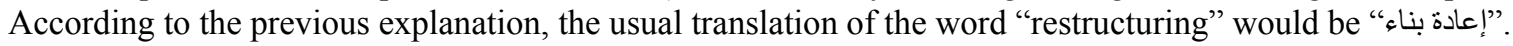

Another essential point that should also be noted is that Abu Deeb adds the syllable وية Arabic to express the English meaning in a more formal way among words which contain extra syllables, e.g., (scientistic-humanistic). Before discussing examples, I should note here that Kamal Abu Deeb is the first translator to use this technique.

\begin{tabular}{|c|c|c|c|}
\hline Science & علم & Scientistic & علموية \\
\hline Human & إنسان & Humanistic & إنسانوية \\
\hline Popular & شعبي & Populist & شعبوية \\
\hline Technique & تقنية ـ تكنيك & Technology & تقنوية \\
\hline
\end{tabular}


In addition, Abu Deeb comes up with a number of prefixes and makes new use of already existing prefixes for the sake of generating concise Arabic notions that are capable of conveying the essence of the English text in an equally succinct style. These include:

- لي ليس a contraction of (لي ) to stand for "a" in negated words such as "ahistorical" (not historical), which he translated as ليتاريخي

- to stand for "over" or "super", such as "super-political" which he translated as فوسياسي

- الزئ (ز ائف (a contraction of stand for "pseudo", such as "pseudo-scientific" which he translated as الزيـ - علمي

- إضافي - زائد إلد ) to stand for "extra", such as "extra-academic" which he translated as زا - جامعي

Moreover, Abu Deeb coined new words which did not previously exist in the Arabic language, like which is a rendered word for the English "socioeconomic", and the word جتماسي for the English word "sociopolitical"; these new vocabularies led to readers being confused, as the words are novel not only at the level of the meaning but also concerning their forms and pronunciation. Another point that should be noted here is that Abu Deeb rendered the English formula 1830s as [ [ ] [1830], which resembles a mathematical way of writings. Although it would be much simple to the readers if he had translated it as ثلاثينات القرن الثامن عشر.

Another new morphological item created by Abu Deeb is تحترضية which contains تحت (under) and أرض (ground), standing for the English word "underground". Al-Herthani (2009, p. 135) notes that this term has a well-established political equivalent in Arabic, namely سري (secret). Abu Deeb uses another word to mean "irrational fear and hatred of foreigners" as a translation of the word (xenophobia). The Arabic equivalent which he has used is not a standard expression and I would suggest the following translation: الخوف المرضي من رُهابُ الأجانب الأجانب. The word استجنابية is regarded as a model for the vocabulary of Abu Deeb that does not convey the meaning and has no equivalent in the mind of the Arabic reader.

By the same token, I agree, as a reader before being a researcher, that the words listed in the index of terms that Abu Deeb included at the beginning of Orientalism, might be completely new to Arab readers and consequently could prevent them from the cognitive enjoyment of the book, as a result of the words having no cultural and memory echo (see Abu Deeb, 1981-1995, p. 21).

Hashim Salih (1980) was one of the first Arab translators who attempted to translate the word "discourse" into Arabic as الخطاب (speech). According to Al-Herthani (2009, p. 136) the term الخطاب has become considered the most common Arabic equivalent of "discourse". Despite that, Abu Deeb made the decision not to use the equivalent established by Hashim and chose the term الإنثاء instead (insha' - composition) to translate the word "discourse" instead of the other common meaning of the word in Arabic which is الخطاب. Abu Deeb defends his point of view by saying that the word الخطاب expresses the meaning better than الإنثاء , because the word الإنشاء revives an old idiom, and easily accepts inflection, e.g., إنشائي "discursive" could inflect the verb أنشأ "compose"

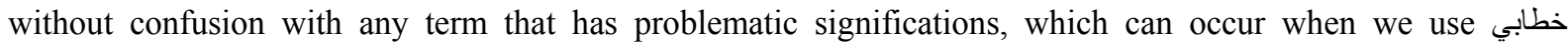
“discursive" or the verb خاطب "to give a speech" (see Abu Deeb, 1981, 1995, p. 17).

As has been previously stated Abu Deeb, for the sake of justifying his linguistic style in translation, stated that the Arabic language is not as sacred as the text of The Holy Quran, and it accepts development. But in the case of translating the title of the book Culture and Imperialism to الثقافة والإمبريالية, he did not change the word الإمبريالية to the word الاستعمار. Although he strives to avoid borrowing from English, Abu Deeb uses the Arabic loan word as a substitute for the English "imperialism". Thus, this choice contradicts his intention of developing the Arabic language. Abu Deeb (1997, p. 47) states that the English word is very common in Arabic and carries different significations that he was not able to express using one Arabic word. Thus, he was overwhelmed by the word "imperialism", for months and tried to find an appropriate translation for it, but could not.

Through this approach, Abu Deeb is trying to inform the reader that the difficulty of finding proper equivalences should be dealt with by adopting a form of creativity and adventure on the side of the translator, and not by regarding language as a "sacred entity" that cannot be touched or improved (see Abu Deeb, 1981, 1995, p. 12).

$$
\begin{aligned}
& \text { نو اجه مشكلة المصطلح بالجر أة، والابتكار ، و المغامرة باستخدام اللغة لا باعتبار ها وجودأ نهائيًا مقدسأ لا يمس، بل بوصفها عملية مستمرة من } \\
& \text { التو الد الاصطلاحي. } \\
& \text { (كمال أبوديب, 1981, 1995, p. 12) }
\end{aligned}
$$

Thus, Abu Deeb's standpoint is that language is not a sacred thing that cannot be changed in any way, but rather 
a continuous process of generating terminologies, and the development of civilization, which is based on the improvement of language that occurs when the linguistic dimension of the cultural development process appears all of a sudden as if it has imploded. However, this imploding is not going to take place without some daring exploration concerning the language. Theoretically, Abu Deeb's declarations in his introduction (of Orientalism) were put into practice in his translation of Orientalism, and by this rendering, he tried to ensure that we have the ability to assimilate, and to remove the quality of sacredness from the language so that he (Abu Deeb) would be capable of preparing himself to create new Arabic terms that would correspond to the English ones. No doubt Abu Deeb might have paid attention to such terms and exerted a lot of effort. However, it would be helpful if these inventions were discussed before using them in translating an important book that had not been translated into Arabic before.

\section{Conclusion}

Abu Deeb $(1981,1995$, p. 9) states that he would be simplifying the matter if he described Said's book as being difficult, for both reading and translating. He also regards Said's style as being very sophisticated, to the extent that he is able to deal with the English language at all levels. However, as we have seen in previous analyses attempted in the present paper, Abu Deeb's translation method can be said to be less effective, as he supports mechanical transference of structure, in addition to the obscurity and ambiguity as seen in the examples supplied in the present paper.

This analysis has suggested that Abu Deeb's method was effect on the style of text, because he calls for a mechanical transference of structure, thus rendering the TT not just "foreign" but obscure and ambiguous as seen in the examples analysed in the present paper. To sum up, Abu Deeb employs this technique to enrich Arabic literature and culture and he experiments with the Arabic language when he renders Said's texts, as a part of the his project. However, his translation of Orientalism has proved controversial in the Arab World.

The translation of Orientalism by Abu Deeb was certainly constructed in a way that would influence the reception of the book and its author in the Arab world for a considerable number of years. Abu Deeb's translation choices labeled Said's writing as inaccessible, complex and demanding an outstanding level of intelligence from the reader.

Abu Deeb's method was not a success because it minimized the importance of Arabic; the Arabic language became unable to be understood by its speakers according to Mona Ibrahim (2004, p. 1032). Immersed in his conceptual narrative of language and translation she noted that Abu Deeb failed to consider the modern Arab audience's needs and power relations that characterise the world today. Mona Ibrahim (ibid, p. 1032) states that his claim of invisibility is false given the [obvious] signs of his dominating presence. The failure to consider the power relations that characterise the modern world is the major failing of this translation which leads to the assimilation of the Anglo-American mechanisms of cultural hegemony over the third world countries, and that Abu Deeb's translation is hardly resistant at all, if not submissive altogether.

\section{References}

Al-Herthani, M. (2009). Edward Said in Arabic: Narrativity and Paratextual Framing (Unpublished doctoral dissertation). University of Manchester, Manchester.

Baker, M. (2000). In other Words: A Coursebook on Translation. London: Routledge.

Boase-Beier, J. (2006). Stylistic Approaches to Translation. Manchester: St. Jerome.

Byaoumi, M., \& Andrew, R. (2000). The Edward Said Reader. New York and Toronto: Vintage Books.

Chesterman, A., Gallardo, S., \& Gambier, Y. (Eds.). (2000). Translation in Context: Selected Contributions from the EST Congress. Amsterdam; Philadelphia: J. Benjamins. http://dx.doi.org/10.1075/btl.39

Fadl, S. (2006). On Admiring Kamal Abu Deeb and his criticism. Yemen Time.

Hafez, S. (2004). Edward Said's Intellectual Legacy in the Arab World. Journal of Palestine Studies, 33(3). http://dx.doi.org/10.1525/jps.2004.33.3.076

Hammuda, A. (1998). Convex Mirrors: From Structuralism to Deconstruction. Kuwait: The National Council for Culture, Arts and Literature.

Ibrahim, M. (2004). Edward Said: The Most Apparent Hidden: A Postcolonial Reading of Abu Deeb's Translation of Said's Orientalism. Conference Proceedings (pp. 1019-1035). Cairo: Supreme Council of Culture.

Paulin, T. (2004). Writing to the moment. The Guardian, Saturday 25.09. 
Said, E. (2003). Orientalism. London: Penguin.

Searle, J. (1979). Expression and Meaning: Studies in the Theory of Speech Acts. Cambridge: Cambridge University Press. http://dx.doi.org/10.1017/CBO9780511609213

Sperber, D., \& Wilson, D. (1995). Relevance: Communication and cognition. Oxford: Blackwell.

Venuti, L. (2000). The Translation Studies Reader. London and New York: Routledge. http://dx.doi.org/10.4324/9780203446621

Vinay, J. P., \& Darbelnet, J. (1995). Comparative Stylistics of French and English: A Methodology for Translation (H. Weaver, Trans.).

$$
\begin{aligned}
& \text { عصفور، جابر. (2007). "منظور مغاير للأدب العربي، مجلة العربي، 580، }
\end{aligned}
$$

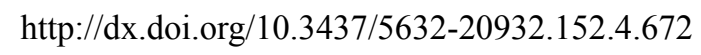

$$
\begin{aligned}
& \text { الأحمري، محمد. (2003). ”إدو ارد سعيد لو كان مسلما لترحمنا عليه، مجلة العصر ، } \\
& \text { http://dx.doi.org/11.9804/2150-65789.792.4.183 } \\
& \text { الدقالح، عبدالعزيز. (2000). ثلاثيات النقاية، بيروت، المؤسسة الجامعية للنشر وتوزيع. }
\end{aligned}
$$

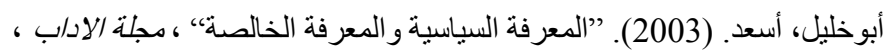

$$
\begin{aligned}
& \text { http://dx.doi.org/11.5496/3246-78021.813.7.980 } \\
& \text { سعيد، إدو ارد. (1981). الإستشراق : الدعرفة ، السلطة ، الإنشاء ، نقله إلى العربية كمال أبو ديب ، الطبعة الأولى ، بيروت ، مؤسسة الأبحاث } \\
& \text { العربية إبرازية. }
\end{aligned}
$$

\section{Notes}

Note 1. The term تفجير would normally be translated as "exploding", but in the context of Abu Deeb's project and based on his discussion, a more appropriate term to use as equivalent might be "implode". Unlike exploding, which takes place on the outside, imploding involves working from the inside, i.e., developing and expanding the deep and surface structures of the language rather than borrowing another language's lexis and structures.

\section{Copyrights}

Copyright for this article is retained by the author(s), with first publication rights granted to the journal.

This is an open-access article distributed under the terms and conditions of the Creative Commons Attribution license (http://creativecommons.org/licenses/by/3.0/). 